
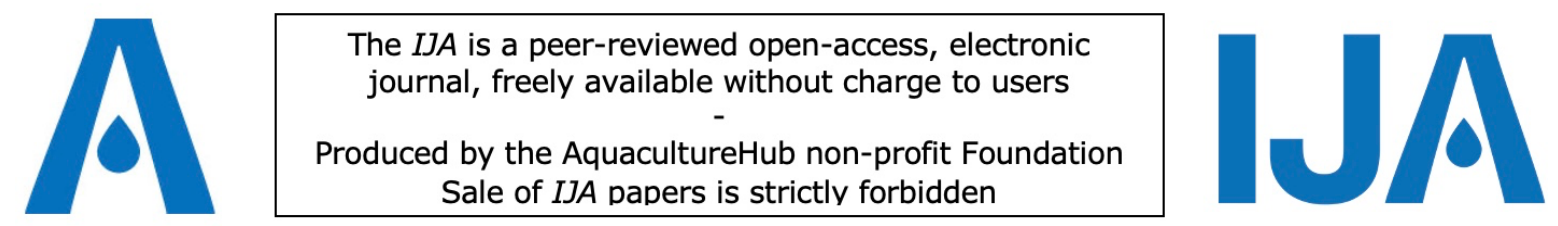

\title{
Effects of feeding strategies on growth, body composition, intestine digestive enzymes activities and intestine histology of Megalobrama pellegrini (Tchang, 1930) early juveniles raised in flow-through system
}

\author{
Huantao Qu ${ }^{1 *}$, Lei Chen ${ }^{1}$, Jinyuan Yang ${ }^{1}$, Jianxin Liao², Dai Wei², and \\ Xuebao Lu'
}

${ }^{1}$ Institute of Chinese Sturgeon, China Three Gorges Corporation, Hubei key laboratory of Three
Gorges Projects for conservation of fishes, Hubei Yichang 443100;

${ }^{2}$ China Three Gorges Projects Development Co., Ltd, Sichuan Chengdu 610041

Key words: Megalobrama pellegrini, feeding rate, feeding frequency, growth performance, intestinal histology

\begin{abstract}
To determine the effects of feeding rate and feeding frequency on growth performance, digestive enzymes activities, and intestine development of Megalobrama pellegrini in a replicated flow-through system, we conducted a 42day experiment. We designed three feeding rates $(5 \%, 6.5 \%$, and $8 \%$ body weight/day, BW/d) and two feeding frequencies ( 2 and 3 meals/day; m/d) in this experiment. Fish $(0.57 \pm 0.01 \mathrm{~g})$ were distributed into 18 tanks with 70 individuals and fed with a commercial diet (33\% crude protein, $4 \%$ total lipid). Results showed that the highest weight gain was found in the fish fed diet with $6.5 \% \mathrm{BW} /$ day and $3 \mathrm{~m} / \mathrm{d}$, which was significantly higher in comparison with that of other feeding rate groups ( $5 \% \mathrm{BW} / \mathrm{d}$ and $6.5 \% \mathrm{BW} / \mathrm{d})$ at both feeding frequency ( 2 and $3 \mathrm{~m} / \mathrm{d}$ ). Fish growth performance was significantly affected by the feeding rate but not by the feeding frequency. The significantly higher feed conversion ratio (FCR) was recorded at $8 \% \mathrm{BW} / \mathrm{d}$ with $3 \mathrm{~m} / \mathrm{d}$ than other treatments. Furthermore, fish fed diet at $8 \%$ BW/d with $2 \mathrm{~m} / \mathrm{d}$ had significantly high mortality during the middle of this trial. In contrast, we found that other fish groups' survival rates were higher (over 90\%), and there were no significant differences among them. We saw a significantly lower whole-body crude protein, lipid, and intestinal digestive enzymes in fish fed at a ratio of $8 \% \mathrm{BW} / \mathrm{d}$ with 3 $\mathrm{m} / \mathrm{d}$ compared with other treatments. Moreover, our findings revealed intestinal villi fusion and exfoliation in this group compared with other treatments. In conclusion, the Megalobrama pellegrini received a feeding rate of $6.5 \% \mathrm{BW} / \mathrm{d}$, and a feeding frequency of $2 \mathrm{~m} / \mathrm{d}$ may be the optimum feeding regime for raising Megalobrama pellegrini in a flow-through system.
\end{abstract}

* Corresponding author. Huantao Qu; e-mail: quhuantao35@163.com 


\section{Introduction}

Nutritional and environmental factors are vital for the commercial success of aquaculture. Adequate and nutritional balanced feed should be offered to obtain the maximum growth and economic profitability of cultured fish during the grow-out phase (Rowland et al., 2005). On the contrary, overfeeding is also disadvantageous for the fish such as reducing feed conversion efficiency and growth, causing deterioration of water quality and increasing costs as feeding accounts for over $50 \%$ of the total operating costs in aquaculture (Okorie et al., 2013). Therefore, the optimum feeding rate has been intensively studied in numerous aquaculture species over the past few decades (Filho et al., 2013; Bakhshalizadeh et al., 2018). Factors including water temperature, feed nutrient compositions, and fish life stage were demonstrated to influence the optimal feeding rate for specific fish species (Yang et al., 2019).

Compared with feeding rate, feeding frequency is another important component of feeding management and is practically meaningful in aquaculture since it could affect fish growth, feed utilization and labor cost of in fish farming (Rahman et al., 2017). Studies also showed that an optimum feeding frequency altered body composition and metabolic molecules, generated homogenous batches (lower coefficient of size variation), and improved water quality especially in intensive culture (Sung-Long, 2018). However, inadequate feeding frequency was related to retarded growth, increased intra-specific aggressions and size variation, impaired anti-oxidation ability, and then resulting in a reduction of profitability (Tian et al., 2015; Fan et al., 2018). Thus, determining the optimum feeding strategies of cultured fish species is crucial for the successful aquaculture industry.

The fish gut plays a fundamental role in digestion and absorption of nutrient and the morphology studies of digestive tract were considered as an effective tool for understanding these processes (Giorgini et al., 2018). And the digestive physiology can also be investigated through the analysis of digestive enzymes activities (Lopezlopez et al., 2005). Like the dietary composition of the feed provided, feeding strategies can also influence the activities of digestive enzymes in fish (Silva et al., 2019). However, little research concerning the morphology digestive tract and digestive enzymes were affected by the feeding strategies, and the analysis of these parameters could be useful to evaluate the relationship between digestible physiology and feeding frequency.

Megalobrama pellegrini is allocated in the main stream and tributaries along the upper reaches of the Yangtze River in the Sichuan Basin of China and is considered to be a well famous domestically species. However, this fish has becoming endangered recently due to overfishing and other human activates (Li et al., 2007). In comparison with other cultured species, the studies of nutrition and husbandry management on Megalobrama pellegrini are quite limited. Thus, this trial aimed to determine the effects of feeding rate and feeding frequency on growth, feed utilization and digestive enzymes activities of Megalobrama pellegrini.

\section{Fish management}

\section{Materials and Methods}

We received fry of Megalobrama pellegrini from the Institute of Chinese Sturgeon and kept them at the Xiang Jiaba experimental station of China Three Gorges Projects Development Co., Ltd, Sichuan, China. Fish were kept in tanks filled with flow-through system $(150 \mathrm{ml} / \mathrm{s})$ and fed with commercial diets (1-2 mm in diameter) containing $33 \%$ crude protein and $4 \%$ crude fat (Sichuan Tongwei Company, Chengdu, China). After one week of acclimation, 1260 fish (0.57 \pm $0.01 \mathrm{~g}$ ) were distributed into eighteen $200 \mathrm{~L}$ tanks and fed with two feeding frequency ( 2 meals/d at 0900 and $1800 \mathrm{~h}$ and 3 meals/d at 0800,1200 , and $1800 \mathrm{~h})$ and three feeding rate $(5 \%, 6.5 \%$ and $8 \%$ of body weight per day [BW/d]). Triplicate was set up for each treatment and the experiment lasted for 42 days. Fish were weighed every two weeks and feed intake was adjusted based on the body weight. Dissolved oxygen was $6.11 \pm 0.3 \mathrm{mg} / \mathrm{L}$ and water temperature maintained at $25.0 \pm 0.4^{\circ} \mathrm{C}$.

Sampling and analysis

At the end of trial, all fish starved for $24 \mathrm{~h}$ before sampling. 10 fish were collected to analyze whole-body proximate. Moisture was determined using a dry oven at $105^{\circ} \mathrm{C}$ to constant weight. Crude protein was estimated by the Kjeldahl method (FOSS Tecator, Sweden). Total lipid was determined by a Soxtec System HT6 (Haineng SOX406, Shandong, China).

Intestine was collected from 5 fish after anesthetized with MS-222 $(10 \mathrm{mg} / \mathrm{L})$ and stored in liquid nitrogen for enzymes analysis. The activities of proteases, lipase, amylases and alkaline 
phosphatase were analyzed by using the commercial kits (Nanjing Jiancheng Bioengineering Institute, Nanjing, China) according to the manufactory instructions.

Mid-gut was sampled from 5 fish and kept in 4\% buffered formalin for histology analysis. The fixed mid-gut for histology analysis were dehydrated in graded ethyl alcohol and then embedded in paraffin. The samples were cut serially at $7 \mu \mathrm{m}$ thickness and were stained with hematoxylin and eosin. The photos were taken using a light microscope with a color video camera (Nikon Ni-U, Japan).

Data are presented as mean \pm SE and were subjected to one-way ANOVA with feeding rate and feeding frequency as factors using IBM SPSS Statistics version 19.0 (IBM, Armonk, New York). Duncan's multiple range tests was used for comparison of the treatments with significance at the $5 \%$ level.

\section{Results}

The effects of feeding strategies on fish growth, feed utilization and survival are presented in Table 1. Significantly higher WG and SGR were found in fish fed with $6.5 \% \mathrm{BW} / \mathrm{d}$ at both feeding frequency respectively $(P<0.05)$, and there was no further significantly improvement in growth performance as the feeding frequency increasing from $2 \mathrm{~m} / \mathrm{d}$ to $3 \mathrm{~m} / \mathrm{d}$ at the feeding rate of $5 \%$ BW/d and $6.5 \%$ BW/d $(P<0.05)$. And the lowest WG and SGR were obtained in fish fed $5 \%$ BW/day divided into $2 \mathrm{~m} / \mathrm{d}$. The significant higher FCR was obtained in the group fed $8 \% \mathrm{BW} / \mathrm{d}$ at $2 \mathrm{~m} / \mathrm{d}$ compared with other treatments $(P<0.05)$. The fish fed diet with $8 \% \mathrm{BW} / \mathrm{d}$ at $2 \mathrm{~m} / \mathrm{d}$ were almost dead during the experiment (data not shown). But no significant difference was found in SR among other groups $(P>0.05)$ and the values were all over $96 \%$.

Whole-body compositions of Megalobrama pellegrini after 42-days experiment are shown in Table 2. Fish had significantly higher whole-body moisture, protein, and lower lipid when fed at $6.5 \% \mathrm{BW} / \mathrm{d}$ compared with $5 \% \mathrm{BW} / \mathrm{d}$ at $2 \mathrm{~m} / \mathrm{d}(P<0.05)$. However, fish whole-body moisture significantly decreased as feeding rate increased at $3 \mathrm{~m} / \mathrm{d}(P<0.05)$. And the significant higher and lower whole-body moisture was recorded at $5 \%$ BW/d with $3 \mathrm{~m} / \mathrm{d}$ and $8 \%$ BW/d with $3 \mathrm{~m} / \mathrm{d}$, respectively. Feeding strategies also had significantly effects on whole-body crude protein and crude lipid. Fish fed at $6.5 \%$ BW/d with $2 \mathrm{~m} / \mathrm{d}$ had significantly higher whole-body crude protein compared with other treatments, but significant higher whole-body crude lipid was recorded in $5 \% \mathrm{BW} / \mathrm{d}$ with $3 \mathrm{~m} / \mathrm{d}$ group compared with other treatments $(P<0.05)$. Significant lower wholebody crude protein and crude lipid were both found in fish fed $8 \% \mathrm{BW} / \mathrm{d}$ with $3 \mathrm{~m} / \mathrm{d}$ compared with other treatments $(P<0.05)$.

The effects of feeding strategies on fish intestine digestive enzymes activities are shown in

Table 3. Intestine trypsin, a-amylase and alkaline phosphatase activities were significantly increased as feeding rate increasing from $5 \% \mathrm{BW} / \mathrm{d}$ to $6.5 \% \mathrm{BW} / \mathrm{d}$ at the $2 \mathrm{~m} / \mathrm{d}$, but they were significantly decreased as feeding rate increasing from $5 \% \mathrm{BW} / \mathrm{d}$ to $8 \% \mathrm{BW} / \mathrm{d}$ at the $3 \mathrm{~m} / \mathrm{d}$ $(P<0.05)$. Higher intestine digestive enzymes activities were found in $5 \% \mathrm{BW} / \mathrm{d}$ and $3 \mathrm{~m} / \mathrm{d}$ compared with other groups.

Megalobrama pellegrini fry fed with different feeding strategies for 42 days generally showed histological health characteristics except the highest feeding rate $(8 \% \mathrm{BW} / \mathrm{d})$ and feeding frequency $(3 \mathrm{~m} / \mathrm{d}$ ) group (Figure 1). Specifically, intestine epithelial cells were in good condition and no signs of cell damage; microvilli were arranged in neat rows. Oppositely, we observed intestine villi fusion and exfoliation in fish fed diet at $8 \%$ BW/d with $3 \mathrm{~m} / \mathrm{d}$. 
Table 1 Effects of feeding rate and feeding frequency on growth, feed utilization and survival of Megalobrama pellegrini. ${ }^{1}$

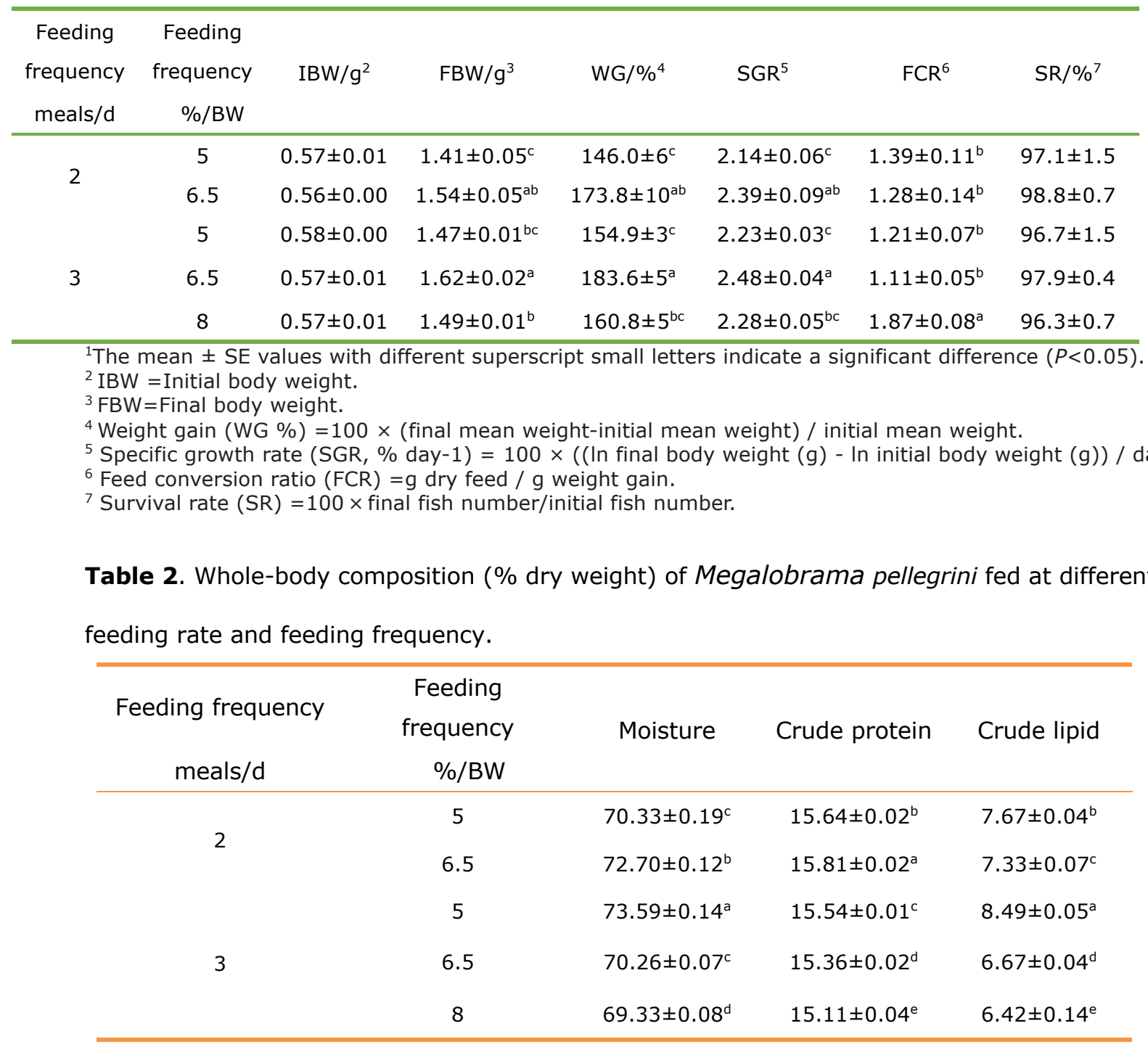

*The mean \pm SE values with different superscript small letters indicate a significant difference $(P<0.05)$.

Table 3. Intestine digestive enzymes activities of Megalobrama pellegrini fed at different feeding rate and feeding frequency.

\begin{tabular}{cccccc}
\hline $\begin{array}{c}\text { Feeding } \\
\text { frequency } \\
\text { meals/d }\end{array}$ & $\begin{array}{c}\text { Feeding } \\
\text { frequency } \\
\% / B W\end{array}$ & $\mathrm{U} / \mathrm{mg}$ & $\mathrm{U} / \mathrm{g}$ & $\mathrm{U} / \mathrm{mg}$ & $\begin{array}{c}\text { Alkaline } \\
\text { phosphatase }\end{array}$ \\
\hline 2 & 5 & $11.10 \pm 0.30^{\mathrm{c}}$ & $335 \pm 8.14^{\mathrm{d}}$ & $0.16 \pm 0.03^{\mathrm{b}}$ & $10.70 \pm 0.13^{\mathrm{c}}$ \\
& 6.5 & $12.77 \pm 0.37^{\mathrm{ab}}$ & $538.1 \pm 13.9^{\mathrm{b}}$ & $0.17 \pm 0.03^{\mathrm{ab}}$ & $12.06 \pm 0.25^{\mathrm{b}}$ \\
& 5 & $13.42 \pm 0.62^{\mathrm{a}}$ & $651.9 \pm 9.57^{\mathrm{a}}$ & $0.18 \pm 0.03^{\mathrm{a}}$ & $14.77 \pm 0.25^{\mathrm{a}}$ \\
3 & 6.5 & $11.91 \pm 0.26^{\mathrm{b}}$ & $440.6 \pm 10.5^{\mathrm{c}}$ & $0.15 \pm 0.02^{\mathrm{c}}$ & $11.53 \pm 0.19^{\mathrm{b}}$ \\
& 8 & $9.84 \pm 0.19^{\mathrm{d}}$ & $244.5 \pm 22.19^{\mathrm{e}}$ & $0.15 \pm 0.02^{\mathrm{c}}$ & $10.27 \pm 0.21^{\mathrm{c}}$ \\
\hline
\end{tabular}

*The mean \pm SE values with different superscript small letters indicate a significant difference $(P<0.05)$. 

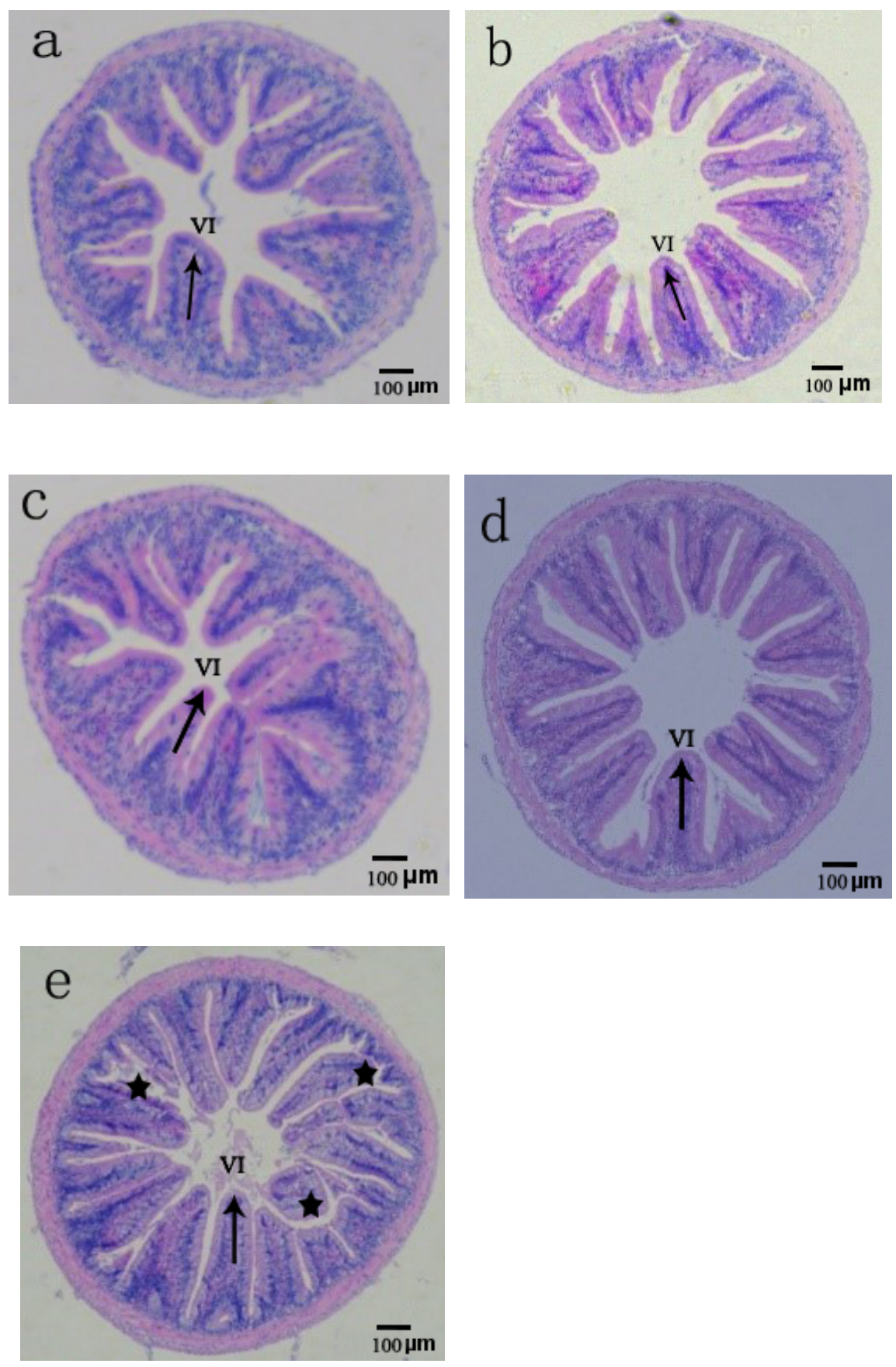

Figure 1 Sections of the mid-gut of Megalobrama Pellegrini fed with different feeding strategies for 42 days. (a) $5 \% \mathrm{BW} / \mathrm{d}$ at 2 time/day; (b) $6.5 \% \mathrm{BW} / \mathrm{d}$ at 2 time/day; (c) $5 \% \mathrm{BW} / \mathrm{d}$ at 3 time/day; (d) $6.5 \%$ BW/d at 3 time/day; (e) $8 \%$ BW/d at 3 time/day。(a), (b) (c) (d): showed the normal intestinal tract $(40 \times)$. (e): intestine exhibited villi fusion and exfoliation (stars) $(40 \times)$.

Abbreviation: villi (VI)

\section{Discussion}

Increasing evidence showed that the optimum feeding strategy is important for aquaculture from both efficiency and economical perspective (Pedrosa et al., 2019). Our results showed that growth performance was significantly affected by the feeding rate, which was in agreement with the 
study in Nile tilapia (Oreochromis niloticus) (Silva et al., 2020). But in the study of Atlantic Spadefish and hybrid sturgeon, Acipenser schrenckii Brandt우 $\times$ A. baeri Brandt $\hat{\delta}$, weight gain was significantly affected by both feeding rate and frequency (Trushenski et al., 2012; Luo et al., 2015). And our results also showed that optimum feeding rate $(6.5 \% \mathrm{BW} / \mathrm{d})$ exhibited significantly higher growth compared with lower ones (5\% BW/d) and higher ones ( $8 \% \mathrm{BW} / \mathrm{d})$. Thus, this was similar with other studies that suboptimal feeding led to malnutrition and retarded the grow performance of fish. Oppositely, the excess nutrients such as protein could be oxidized for energy substrate and subsequent waste products such as ammonia and thus affect animal well-being (Guang et al., 2012). However, some fish species continuously increased of weight gain with the increasing feeding rate up to satiation, such as white sturgeon, Acipenser transmontanus (Deng et al., 2003) and European sea bass, Dicentrarchus labrax L. (Eroldogan et al., 2004). These results showed that the optimum feeding rate varied based on the fish size, fish species, and experiment conditions.

Our results showed that no significantly difference was found in WG as feeding frequency increasing from $2 \mathrm{~m} / \mathrm{d}$ to $3 \mathrm{~m} / \mathrm{d}$, which was accordance with the findings in silver perch Bidyanus bidyanus (Rowland et al., 2005) and Brazilian sardine Sardinella brasiliensis (Baloi et al., 2016). But the studies in hybrid bream (Wu et al., 2018) and golden pompano (Trachinotus ovatus) (Wu et al., 2015) exhibited higher WG when fed $3 \mathrm{~m} / \mathrm{d}$ than $2 \mathrm{~m} / \mathrm{d}$. Gilannejad et al. (2019) indicated that the apparent digestibility coefficient was improved by increasing feeding frequency, but the effects on stomach and intestine evacuation rates were species dependent. But our study showed that FCR was not significantly affected by the feeding frequency. What is more, feeding frequency could be also affected by dietary composition (Zhao et al., 2016). Even no growth promoted effect as feed frequency increased, but the survival rate was significantly improved when fish fed $3 \mathrm{~m} / \mathrm{d}$ compared with $2 \mathrm{~m} / \mathrm{d}$ at highest feed rate (8\% BW/d). Jobling and Baardvik (1994) suggested that higher feeding frequency could increase feed intake up to a threshold when fish fed to apparent satiety. So, it could be speculated that increased feeding frequency could relieve the digestive and metabolism burden when ingested much more diet. While in the study of Atlantic salmon (Salmo salar), fish mortality was only significantly affected by the feed rate, and increased feed frequency did not improve survival rate of fish (Sun et al., 2016)

Fish body composition could be affected not only by nutritional factors but also by the feeding strategy (Jobling and Johansen, 2003). And whole-body composition could be used as a sign of optimum feeding strategy for cultured fish (Zhang et al., 2011). Feeding strategy had a significant effect on the whole-body composition of Megalobrama pellegriniin our study. And the lowest whole-body protein and lipid were found in fish fed at feeding rate $8 \% \mathrm{BW} / \mathrm{d}$ and $3 \mathrm{~m} / \mathrm{d}$. It has been suggested that improving feeding frequency could reduce energy expenditure for food competition, which will facilitate the protein and lipid to deposit in the body (Xie et al., 2011). However, this case was only found in the whole-body lipid when fish fed with the lowest feeding rate $(5 \% \mathrm{BW} / \mathrm{d})$ in our study, which could be associated with fish size, species, and rearing conditions as suggested by Mizanur and Bai (2014). Huang et al. (2015) reported that the significant interaction effect was only found on whole-body crude lipid, but not on the crude protein of tilapia. However, in the study of tilapia cultivated in bioflocs, whole-body proximate was only affected by the feeding frequency or feeding rate respectively (Silva et al., 2020). And some results also showed that whole-body proximate was not affected by the feeding strategy such as hybrid sturgeon (Luo et al., 2015) and gibel carp (Carassius auratus gibelio) (Zhou et al., 2003).

Increased knowledge of the development and structure of digestive tract during growth is essential for understanding the digestive and nutritional physiology of fish (Khojasteh et al., 2009). In the present study, typical changes of intestinal histology were appeared when fish fed at $8 \% \mathrm{BW} / \mathrm{d}$ and $3 \mathrm{~m} / \mathrm{d}$. Thus, the diminished of absorption area of the intestine might be caused low efficiency of nutrient utilization, which also matched with the increased FCR and growth retarded in this group. Imsland et al. (2019) found that the disordered lamina epithelialis, extended lamina propria, and inflammation were present in lumpfish (Cyclopterus lumpus L.) fed daily compared with four days per week (4DW) or three days per week. The above studies indicated that improper feed intake may disturb their normal physiological status of digestive ability and then gut healthy could be impaired by this excessive digestion process.

Proteases, lipase and amylases are the main enzymes related to digestion and the absorption of nutrients. So quantification of these enzymes activity is a useful tool to improve knowledge regarding the digestive processes in farmed fish species (Thongprajukaew et al., 
2011). In our study, intestine digestive enzymes activities were significantly affected by the feeding strategy and the lowest values were recorded in $3 \mathrm{~m} / \mathrm{d}$ and $8 \%$ BW/d feeding rate group. Thus, excessive feed intake could decrease enzyme activity to keep from unneeded expenditure. And digestive enzymes activity decreased due to increased feed intake was also found in Brazilian sardines (Sardinella brasiliensis) (Baloi et al., 2017). Tian et al. (2015) reported that the activities of intestinal protease, lipase and a-amylase increased as feeding frequency rose from 1 to 3 times, but they were decreased with further increasing of feeding frequency in Megalobrama amblycephala. In addition, our results showed that enzymes actives were significantly improved by feeding frequency when fish fed with a lower feeding rate $(5 \% \mathrm{BW} / \mathrm{d})$. Thus, proper improved feeding frequency may favor of increasing digestive enzymes activities and further feed utilization (Thongprajukaew et al., 2017). And it is also a utility strategy for fish by keeping highly activities of digestive enzymes to fully utilize the nutrients when the feed is in shortage.

In summary, fish fed at $6.5 \%$ feeding rate with $2 \mathrm{~m} / \mathrm{d}$ was the optimum feeding strategies for Megalobrama Pellegrini early juveniles reared in flow-through system and obtain the best growth performance.

\section{Acknowledgements}

We would like to acknowledge the fish proliferation and release station of xiangjiaba hydropower located at Jinsha River for providing funds for this study from their operation management project. We would also like to thank Hao Cui, Rui Yang and Kaisheng Feng for the assistance of fish management and sampling. No conflict of interest is declared in this article.

\section{References}

Bakhshalizadeh, S., A. Bani, S. Abdolmalaki, and J. T. Poncepalafox, 2019. The effect of feeding rate on growth of pectoral fin spine of juvenile great sturgeon Huso huso (Linnaeus, 1758). Journal of Applied Ichthyology, 35(2), 403-407. DOI:10.1111/jai.13863

Baloi, M., C. V. A. D. Carvalho, F. C. Sterzelecki, G. Passini, and V. R. Cerqueira, 2016. Effects of feeding frequency on growth, feed efficiency and body composition of juveniles Brazilian sardine, sardinella brasiliensis (steindacher 1879). Aquaculture Research, 47:554-560. DOI:10.1111/are.12514

Deng, D. F., S. Koshio, S. Yokoyama, S. C. Bai, Q. Shao, Y. Cui, and S. S. Hung, 2003. Effects of feeding rate on growth performance of white sturgeon (Acipenser transmontanus) larvae. Aquaculture, 217(1-4),589-598. DOI: 10.1016/S0044-8486(02)00461-1

Eroldoğan, O. T., M. Kumlu, and M.Aktaş, 2004. Optimum feeding rates for European sea bass Dicentrarchus labrax L. reared in seawater and freshwater. Aquaculture, 231(1-4), 501515.DOI: $10.1016 / j$.aquaculture.2003.10.020

Fan, X., M. Li, L. Yuan, H. Lai, M. Song, R. Wang, and R. Zheng, 2017. Effects of feeding frequency on the enzymes and genes involved in oxidative stress in juvenile yellow catfish Pelteobagrus fulvidraco (Richardson) exposed to ammonia. Aquaculture Research, 48(12), 58745882. DOI: $10.1111 /$ are. 13410

Filho, R. M., R. Takata, A. E. H. Santos, W. D. S. E. Silva, A. L. Ikeda,L. A. Rodrigues,J. C. E. D. Santos, A.L. Salaro, R. K. Luzand R. K. Luz, 2014. Draining system and feeding rate during the initial development of lophiosilurus alexandri (steindachner, 1877), a carnivorous freshwater fish. Aquaculture Research, 45:1913-1920. DOI:10.1111/are.12139

Giorgini, E., B. Randazzo, G. Gioacchini, G. Cardinaletti, L. Vaccari, E. Tibaldi, and I. Olivotto, 2018. New insights on the macromolecular building of rainbow trout (O. mykiss) intestine: FTIR Imaging and histological correlative study. Aquaculture, 1-9. DOI:10.1016/j. aquaculture.2018.07.032

Gilannejad, N., T. Silva, G. Martínez-Rodríguez, and M. Yúfera, 2019. Effect of feeding time and frequency on gut transit and feed digestibility in two fish species with different feeding behaviours, gilthead seabream and Senegalese sole. Aquaculture, 513, 734438. DOI:10.1046/j. 1365-2109.2001.00635.x

Huang, Q., K. Huang, Y. Ma, X. Qin, Y. Wen, L. Sun, and L. Tang, 2015. Feeding frequency and rate effects on growth and physiology of juvenile genetically improved farmed NileTilapia. North American journal of aquaculture, 77(4), 503-512. DOI:10.1080/15222055. 2015.1066472 
Imsland, A. K., P. Reynolds, T. M. Jonassen, T. A. Hangstad, T. A. Elvegård, T. C. Urskog, and B. Mikalsen, 2019. Effects of different feeding frequencies on growth, cataract development and histopathology of lumpfish (Cyclopterus lumpus L.). Aquaculture, 501, 161-168. DOI: 10. 10 16/j.aquaculture.2018.11.026

Jobling, M., and B. M. Baardvik, 1994. The influence of environmental manipulations on interand intra-individual variation in food acquisition and growth performance of Arctic charr, Salvelinus alpinus. Journal of Fish Biology, 44(6), 1069-1087. DOI:10.1111/j.10958649.1994.

tb01277.x

Jobling, M., and S. J. S. Johansen, 2003. Fat distribution in Atlantic salmon Salmo salar L. in relation to body size and feeding regime. Aquaculture Research, 34(4), 311-316. DOI:10.1046/j. 1365-2109.2003.00820.x

Khojasteh, S. B., F. Sheikhzadeh, D. Mohammadnejad, and A. Azami, 2009. Histological, histochemical and ultrastructural study of the intestine of rainbow trout (Oncorhynchus mykiss). World Applied Sciences Journal, 6(11), 1525-1531. DOI:10.1.1.388.5529

Li, W.J., J.W. Wang, C.X. Xie, D.Q. Tan, 2007. Reproductive biology and spawning habitats of Megalobrama pellegrini, an endemic fish in upper-reaches of Yangtze River basin. Acta Ecol. Sin., 27, 1917-1925.

Luo, L., T. Li, W. Xing, M. Xue, Z. Ma, N. Jiang, and W. Li, 2015. Effects of feeding rates and feeding frequency on the growth performances of juvenile hybrid sturgeon, Acipenser schrenckii Brandt $\bigcirc \times$ A. baeri Brandt ${ }^{\lambda}$. Aquaculture, 229-233. DOI:10.1016/j.aquaculture.2015.06.005

Lopez-Lopez, S., H. Nolasco, H. Villarreal-Colmenares, and R. Civera-Cerecedo, 2005. Digestive enzyme response to supplemental ingredients in practical diets for juvenile freshwater crayfish Cherax quadricarinatus. Aquaculture Nutrition, 11(2),79-85.DOI:10.1111/j.13652095. 2004.00305.x

Mizanur, R. M., and S. C. Bai, 2014. The optimum feeding frequency in growing Korean rockfish (Sebastes schlegeli) rearing at the temperature of $15^{\circ} \mathrm{C}$ and $19^{\circ} \mathrm{C}$. Asian-Australasian journal of animal sciences, 27(9), 1319. DOI:10.5713/ajas.2014.14193

Okorie, O. E., J. Bae, K. W. Kim, M. H. Son, J. W. Kim, and S. C.Bai, 2013. Optimum feeding rates in juvenile olive flounder, Paralichthys olivaceus, at the optimum rearing temperature. Aquaculture Nutrition, 19(3), 267-277. DOI:10.1111/j.1365-2095.2012.00956.x

Pedrosa, R. U., B. O. De Mattos, D. S. Pereira, M. L. Rodrigues, L. G. Braga, and R. Fortessilva, 2019. Effects of feeding strategies on growth, biochemical parameters and waste excretion of juvenile arapaima (Arapaima gigas) raised in recirculating aquaculture systems (RAS). Aquaculture, 562-568. DOI:10.1016/j. aquaculture.2018.10.058

Rowland, S. J., L. Allan, C. Mifsud, M. Nixon, P. Boyd, and D. Glendenning, 2005. Development of a feeding strategy for silver perch, Bidyanus bidyanus (mitchell), based on restricted rations. Aquaculture Research, 36 (14), 1429-1441. DOI:10.1111/j.13652109.2005. 01364.x

Rahman, M. M., and Sangcmin Lee, 2017. Effect of dietary lipid level and feeding frequency on the growth, feed utilization, and body composition of juvenile spotted seabass, lateolabrax maculatus. Journal of the World Aquaculture Society, 48(4):634-642. DOI:10.1111/jwas.12382

Silva, M. A., E. R. De Alvarenga, F. F.Costa, E. M. Turra, G. F. Alves, L. G. Manduca, and E. D. Teixeira, 2020. Feeding management strategies to optimize the use of suspended feed for Nile tilapia (Oreochromis niloticus) cultivated in bioflocs. Aquaculture Research, 51(2), 605-615. DOI: $10.1111 /$ are. 14408

Silva, E. C. D., F. C. Sterzelecki, L. A. Musialak, J. K. Sugai, and V. R. Cerqueira, 2020. Effect of feeding frequency on growth performance, blood metabolites, proximate composition and digestive enzymes of lebranche mullet (Mugil liza) juveniles. Aquaculture Research, 51(3).

DOI: 10.1111 /are.14466.

Sung-Long O., B. A. V. Maran, and J. W. Park, 2018. Effect of feeding frequency on growth, food consumption, proximate composition, and blood chemistry of juvenile dark-banded rockfish, Sebastes inermis. Journal of the World Aquaculture Society, 49(4):9941001.DOI:10.1111/jwas. 12512

Sun, G.H., Y. Liu, D.G. Qiu, M.M. Yi, X. Li, and Y. Li, 2016. Effects of feeding rate and frequency on growth performance, digestion and nutrients balances of atlantic salmon (salmo salar) in recirculating aquaculture systems (ras). Aquaculture Research, 47(1), 176-188. DOI: $10.1111 /$ are. 12480 
Tian, H. Y., D. D. Zhang, X. F. Li, C. N. Zhang, Y. Qian, and W. B. Liu, 2015. Optimum feeding frequency of juvenile blunt snout bream Megalobrama amblycephala. Aquaculture, 437, 60-66.DOI:10.1016/j.aquaculture.2014.11.032

Thongprajukaew, K., U.Kovitvadhi, S.Kovitvadhi, P.Somsueb, and K.RungruangsakTorrissen, 2011. Effects of different modified diets on growth, digestive enzyme activities and muscle compositions in juvenile Siamese fighting fish (Betta splendens Regan, 1910). Aquaculture, 322, 1-9. DOI:10.1016/j.aquaculture.2011.10.006

Thongprajukaew, K., S. Kovitvadhi, U. Kovitvadhi, P. Preprame, 2017. Effects of feeding frequency on growth performance and digestive enzyme activity of sex-reversed Nile tilapia, Oreochromis niloticus (Linnaeus, 1758). Agriculture and Natural Resources, 51(4), 292-298. DOI: $10.1016 / j$.anres.2017.04.005

Trushenski, J. T., A.Rombenso, M. H. Schwarz, J. C. Bowzer, B. Gause, B. Delbos, and L. A. Sampaio, 2012. Feeding Rate and Frequency Affect Growth of Juvenile Atlantic Spadefish. North American Journal of Aquaculture, 74(1), 107-112. DOI: 10.1080/15222055. 20 12.655853

Wu, Y., H. Han, J. Qin, and Y. Wang, 2015. Effect of feeding frequency on growth, feed utilization, body composition and waste output of juvenile golden pompano (trachinotus ovatus) reared in net pens. Aquaculture Research, 46:1436-1443.DOI:10.1111/are.12297

Wu, Y., X. Ren, J. Zhou, H. Lin, X. Wang, and H. Ma, 2019. Feed intake, growth, feed utilization, body composition and waste output of juvenile hybrid bream at different feeding frequencies. Aquaculture Nutrition, 25(2), 292-297. DOI:10.1111/anu.12852

Yang, S., S.Zhai, B. S. Shepherd, F. P. Binkowski, S. S. Hung, W. M. Sealey, and D. Deng, 2019. Determination of optimal feeding rates for juvenile lake sturgeon (Acipenser fulvescens) fed a formulated dry diet. Aquaculture Nutrition, 25(6), 1171-1182.DOI:10.1111/anu.12932

Zhao, H., R. Jiang, M. Xue, S. Xie, X. Wu, and L. Guo, 2010. Fishmeal can be completely replaced by soy protein concentrate by increasing feeding frequency in Nile tilapia (Oreochromis niloticus GIFT strain) less than 2g. Aquaculture Nutrition, 16(6), 648-653.DOI:10.1111/j.13652095.2009.00708.x

Zhou, Z., Y. Cui, S. Xie, X. Zhu, W. Lei, M. Xue, and Y. Yang, 2003. Effect of feeding frequency on growth, feed utilization, and size variation of juvenile gibel carp (Carassius auratus gibelio). Journal of Applied Ichthyology, 19(4), 244-249.DOI:10.1046/j.14390426.2003.00453.x 